\title{
China's role in global competition in the wine industry: A new contestant and future trends
}

\author{
Darryl J Mitry ${ }^{1,2}$ \\ David E Smith ${ }^{2,3}$ \\ Per $V$ Jenster ${ }^{3,4}$
}

'Norwich University, Graduate School Faculty, Northfield, VT, USA; ${ }^{2}$ National University, San Diego, California, USA; ${ }^{3}$ Copenhagen Business School, Copenhagen, Denmark; ${ }^{4} \mathrm{China}$ Europe International Business School, Shanghai, People's Republic of China

Correspondence: David E Smith National University, San Diego, California, USA

Tel + I 949786636 I

Email dsmith8@nu.edu

\begin{abstract}
The producers in the wine industry are competing in an increasingly global marketplace. More specifically this article is interested in China's wine market and the role of China in global competitive strategies. The phenomenal growth of the Chinese economy over the past decade has encouraged international suppliers to enter the Chinese market. International wine suppliers lust after a huge potential market in a country of over 1,300,000,000 people. Simultaneously, there has also been a significant growth of production and marketing of wines by Chinese-owned wineries. This contribution explores the implications of China's marketplace and also China as a creative and strategic producer.
\end{abstract}

Keywords: China, wine, competition

"To make intelligent investments within your organization, you need to understand how your whole industry is changing."1

\section{Competition through strategic marketing}

Modern strategic marketing is a relatively new concept in the wine industry, as not only a subject for academic research, but also in the diffusion of modern methods into industry practice. During the early 1990s the industry began to transition from traditional supply-driven production to market-orientated business models of consumer demand. ${ }^{2}$ The suppliers who were first to recognize these changes have enjoyed tremendous growth and have often become the high volume producers. ${ }^{3}$ These high volume producers have developed systematic marketing strategies. Such suppliers have created extensive portfolios of brands and can adapt to changing consumer preferences more readily. These companies continue to build strength in new business sectors with their far-reaching distribution networks into world markets. ${ }^{4}$ Significant investments are made in advertising campaigns to further entrench portfolio branding, and worldwide sales have been increasing as illustrated in Figure 1.,6

However, in the segmented and complex wine industry, numerous wine producers are simultaneously competing in other ways. Companies are using innovative strategies to focus on specific target markets. The Yellow Tail brand from Australia is an example, and it has succeeded by creating a new market in the USA as well as in Europe and Asia. Another example is the Bonny Doon Company, which uses an unusual selection of wine varieties along with unconventional label designs to attract new market segments. Innovation extends to packaging, branding and advertising. In addition, new industry entrants with fast-moving consumer goods background intensify the need for different competitive strategies. ${ }^{7}$

This article will focus on the Chinese market and its role in global competitive strategies of the wine industry. 


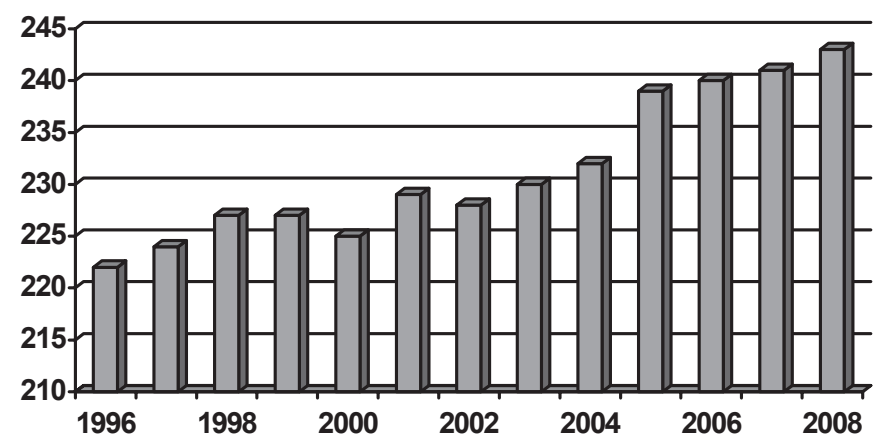

$\square$ Millions HL

Figure I Global wine consumption.

Notes: Based on data from Jenster and colleagues (2008), Euromonitor International, Industry research (2007), and estimated year-end consumption, 2008.

\section{China}

The phenomenal growth of the Chinese economy over the past decade has encouraged international suppliers to export wines to China. Understandably, China is the most populated country in the world and the economy has been growing at over twice the rate of the world average, and thus appears to be one of the largest future markets for many imported products. Indeed international suppliers thirst after the idea of a huge potential market in a country of over $1,300,000,000$ people. Moreover, living standards have improved dramatically since China's adoption of market-oriented economy. ${ }^{8}$ In terms of GDP, China ranks 4th in the world, and ranks second in terms of purchasing power parity. ${ }^{9}$ About 211 million Chinese are middle class in terms of income, and moreover, it appears that over 300 million are middle class according to their consumption patterns, and over 400 million consider themselves middle class. ${ }^{10}$ These are huge numbers no matter how one calculates the population of middle-class consumers. ${ }^{11,12}$ No wonder marketers have been competing vigorously for China's potential markets. As expected, wine sales have been increasing substantially in China for the past five years, as illustrated in Figure 2. ${ }^{5,13}$

The French in particular have been doing well with exports to China and they dream of a huge future market among the emerging middle-class inside the world's fastest

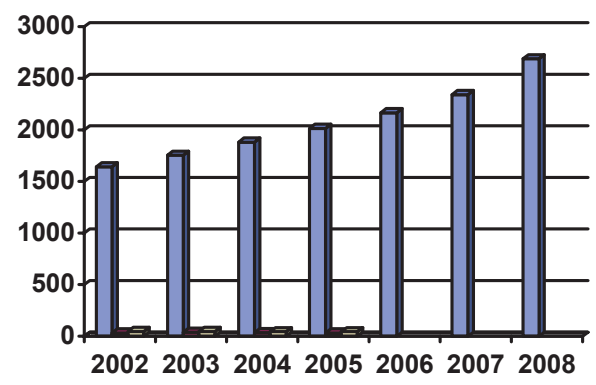

Figure 2 Wine sales in China.

Notes: Based on data from Jenster and colleagues (2008), Euromonitor International (2008), and estimated year-end sales, 2008. growing economy. Simultaneously, there has also been a significant growth of production and marketing of wines by Chinese-owned wineries. Therefore, a very interesting question arises as to how much of a growing market will be claimed by imported wines and how much will eventually be captured by Chinese-owned wine companies. Likewise, there is an interrelated question concerning how much of the global wine market will eventually be captured by the Chinese through their production and strategic exporting. If the recent history of China's export-oriented producers is any indication, many of the world's other wine exporters may eventually be chagrined and disappointed. Instead of the French finding a continually growing market for exports, they may have actually roused a giant competitor who will eventually overtake and reap most of the profits sought by the French and some of the other major wine exporters. What is the likelihood of this future scenario?

\section{Production}

Grapes have been grown in China for thousands of years, more than two millennia, but production was rather negligible until the founding of the People's Republic of China. ${ }^{14}$ Originally, the area under cultivation of grapes and their production were only about 3,200 hectares and 39,000 tons, respectively. ${ }^{15}$ Following China's economic growth, grape production increased rapidly within the country, especially since the 1980's. Under the influence of the "red wine rush" in the Asian countries during the early 1990s, grape growing received another impetus and became a focus of people's attention in China. However, the production of wine from grapes was not as fast to gain interest. ${ }^{16}$

Among hundreds of grape varieties grown in China, the important wine varieties include for white wine are Chardonnay, Italian Riesling, Ugni blanc, Chenin blanc, Gewurztraminer, Sauvignon blanc, Semillon, white Riesling, and Rkatsiteli. The main varieties for red wine are Cabernet 


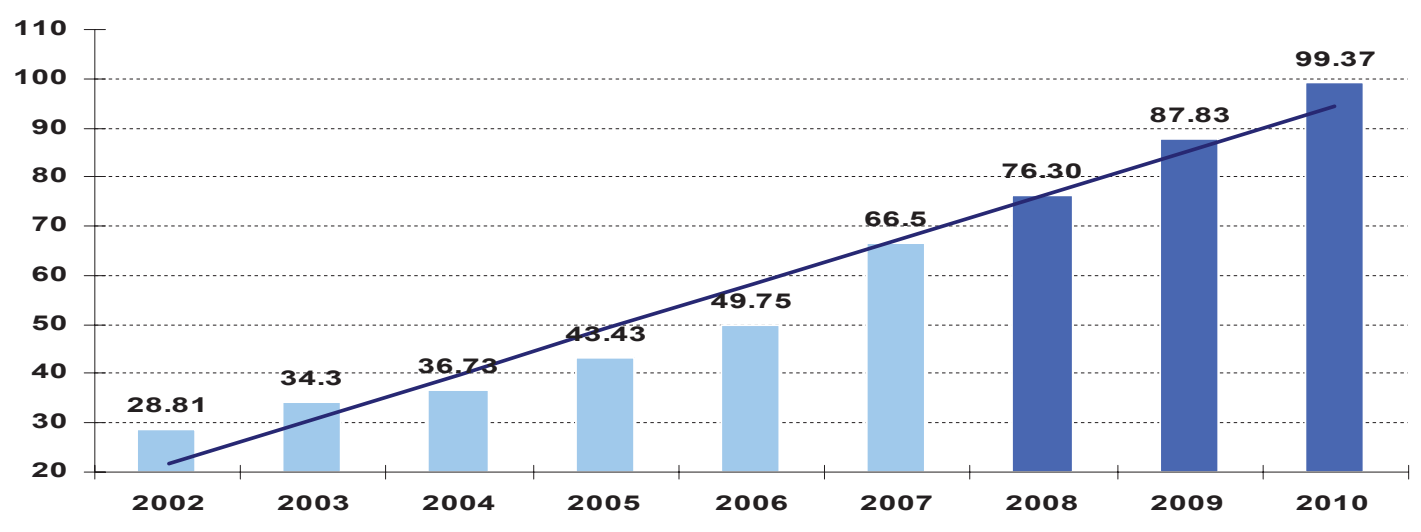

Figure 3 Wine production in China (10 kiloton).

Notes: Based on data from Shao-Hua (2007), Euromonitor International (2007), Wine Institute (2007), and estimates 2008-20I0.

Sauvignon, Cabernet franc, Merlot, French blue, Muscat Hamburg, Pinot noir, Syrah, Carignan, and Saperavi. ${ }^{17}$ China is fortunate in not having any phylloxera pest problems. ${ }^{16}$ Most of the grape-planting material used in the country is therefore propagated by cuttings. ${ }^{17}$

However, in some cold areas vines are grafted on coldresistant rootstocks, such as Beta (a probable hybrid between Vitis riparia and V. labrusca) and lines from Vitis amurensis. Large wine fields without problems of pests are a real competitive advantage for quickly expanding production.

At the time of the founding of the People's Republic of China, the estimated annual production of wine was only 85 tons per year. While the fledgling wine industry has developed rapidly since that time, it is still true that wine production currently contributes only a small portion towards the total alcoholic beverage production within the country. Nevertheless, as the overall economy has been growing at double digits, year after year, the preference for wine consumption had also been growing rapidly, and providing a very desirable domestic market for wine as illustrated in Figure $3{ }^{5,16} \mathrm{In}$ fact, most of the provinces are now engaged in the industry. By 1998, the land area under grape cultivation was estimated to be 55 to 60 times greater than in 1949, and in 2000 there were more than 400 wine companies established in 26 provinces (Figure 4). ${ }^{13,16}$ The five leading provinces have contributed more than two thirds of the total grape production in the country. ${ }^{13}$

The growth of Chinese vineyards has been remarkable and is expected to continue. Indeed, as recent as 2005 China's wine production of 487 million liters from 1150 thousand acres of vineyard exceeded Australia, Chile, and South Africa combined. The growth of vineyard acreage was the highest in the world; more than $113 \%$ over the past five years..$^{18}$ Presently, grape production now ranks fifth in all fruit production in China, and the main areas of expansion are still located

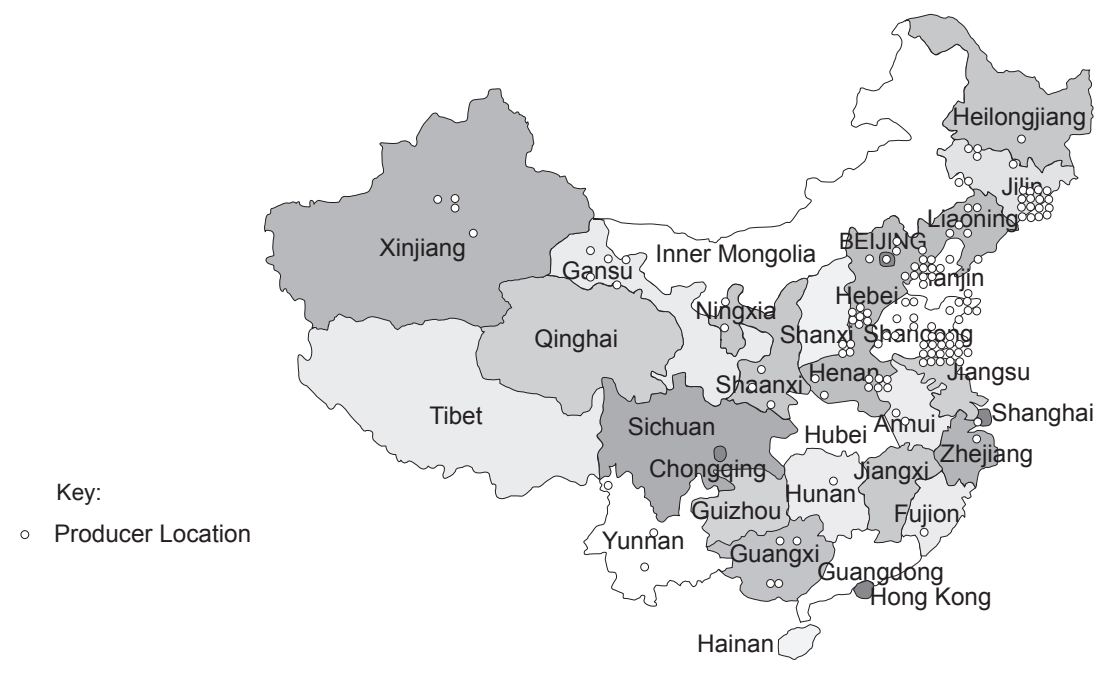

Figure 4 Locations of wine growing in China.

Notes: Based on data from Euromonitor International (2007); Jenster and colleagues (2008); Wine Institute (2007). 
in the north. Moreover, there is significant opportunity to increase vineyard output for production of quality wines.

Although the wine industry in China has made rapid progress in recent years, the per capita production of wine remains relatively small, and the current domestic supply is not entirely satisfying the current consumption demands of the Chinese people. ${ }^{19}$ Therefore, imported wine supplements the domestic supply. Nevertheless, China is the leading source of the global wine industry's volume expansion. Interestingly, the volume gain of 583 million liters of grape wine during 1999 to 2004 was the result of government campaigns encouraging consumers to switch drinks and consume more grape wine in order to preserve national stocks of rice for the production of food. This consumer policy has continued to result in growth of grape wine sales, and can be expected to further advance wine expansion and consumption within China. ${ }^{16}$

\section{Consumption}

Overall wine consumption continues to advance in China. Along with the double digit growth of the economy, annual consumption has also been increasing by double-digits, consistently rising by $10 \%$ or more per annum. ${ }^{5,16}$ This development underscores the change in consumption habits of alcoholic beverages in modern China. ${ }^{20}$ The Chinese have a cultural tradition of consuming alcoholic beverages, especially drinking of spirits distilled from sorghum and maize. This habit remains but the variety of alcoholic drinks has grown considerably. ${ }^{21}$ For example, beer production in tonnage was more than $50 \%$ of the national alcoholic beverage production in 1990, but soon after consumption of wines became the trend. ${ }^{22}$ Wine is a compelling substitute for both beer and spirits in China. More and more people consume wine instead of spirits. In fact, by 2006 China accounted for $6 \%$ of the world wine market, which may be compared to the United States that accounted for $11 \%$ of the market. China has definitely been a growing and is an important market for wine. ${ }^{23}$

There is no question that Chinese consumers appear to present an upside opportunity for the wine marketers of the world because the current per capita consumption is starting from a low base and will more rapidly increase (currently 1.12 liters per capita). There is considerable room for significant increases when considering that France has a per capita consumption hovering around 54 liters and Italy at 49 liters per capita. The per capita consumption of China will increase and this presents a valuable market for wines. ${ }^{24}$ For example, as recently as 2005 China became the world's fastest-growing wine market. According to a note issued by ISI Emerging Markets Database (2006), the total market for wine in China is forecast to reach 16.95 billion RMB by 2011 , growing by about $39 \%$ in $2007 .{ }^{25}$ Indeed, China's wine market is projected to continue to grow substantially and sometime before 2010 it will place 4th in the world markets, only behind France, the United States and Italy in terms of total consumption. ${ }^{26}$ This is understandable because the urban consumer class in China is estimated to exceed the total population of the United States and will almost certainly develop into a large market for wine in the future. ${ }^{27}$

\section{Supply, demand, and trade}

The Chinese consumption of wine is an increasingly important market, but there remains the question of how much of the future demand for wine will be fulfilled by imports and how much will be fulfilled by domestic Chinese producers. Currently, the imported grape wine accounts for only $2 \%$ of volume sales in China, with domestic wine dominating. ${ }^{28}$ As wine importers are competing in the high-end market, their market share in terms of revenue is higher and has witnessed an increase from $6.6 \%$ in 2006 to $10 \%$ in 2007. In 2007, China's imports of wine reached a record high, 54 million bottles/750 $\mathrm{ml}^{29}$

While the wine exporters to China dream of ever increasing profits, they may be disappointed if the Chinese producers out maneuver them, not only in the Chinese market but also by encroaching on markets elsewhere in the world. From April 2007 to April 2008, China's own wine production increased $69.78 \%$. China is now a global economic force, a leader in world exports of many products with certain production advantages that may be impossible to counteract. They have some of the largest agricultural land holdings, and plentiful laborers, a modern capital market with huge financial reserves. Moreover, China has recently assimilated the latest technology and become skillful in contemporary business strategies. The Longhai International Trading Co. Ltd, a Chinese real estate group founded in 2001, has just acquired Chateau Latour Laguens, a wine property in the Entre-DeuxMers region, southeast of Bordeaux. Latour Laguens makes wine in both the Bordeaux and Bordeaux Supérieur categories and produces 160,000 bottles a year from 30 hectares of vines. In recent years the China-based Longhai trading company has branched out into wine business. The rationale behind this acquisition was to master the techniques of winemaking in France and win credit as a wine trader. ${ }^{18}$

A case in point is the Yantai ChangYu Group Company Limited. It is the largest wine production company in China, 
accounting for approximately a fifth of all sales. It was the first industrialized winery in China, headquartered at the coastal city Yantai, Shandong Province. ${ }^{30}$ The winery was established in 1892 by a well-known overseas Chinese merchant, Chang Bishi. Over the past three decades, ChangYu has undergone significant changes. Its sales staff grew from three salesmen in 1989 to 1500 in $2006 .{ }^{30}$ After the 1994 restructure of ownership and privatization in 2004, ChangYu was prepared for substantial growth. In 1997, the company launched an initial public offering of million shares of its common stock on the Shenzhen Stock Exchange, and again in 2000 another offering. ${ }^{30}$

As China was moving away from producing "halfjuice" wine towards serious wine, ChangYu wines have been moving-up the price ladder, with an increased focus on mid-range and high-end wines. For years, ChangYu has been leading the château-building boom in China. In 2001, it formed a strategic alliance with the well-known French wine group Castel. The cooperation took the form of two joint ventures: Castel-ChangYu Wine Co. Ltd., located in Lang Fang, Hebei, and Yantai ChangYu Wine Chateau Co. Ltd.

In 2003, ChangYu-Castel Chateau launched the "barrel ordering" sales mode, which was new in the Chinese wine industry. In 2006, ChangYu also entered the ice wine business by cooperating with Canadian Aurora Ice Wine Co., which successfully planted ice grape vines in China on more than 300 hectares of land in five years. Previously, the yield of global ice wine, restricted by climatic conditions, was confined to Canada and Germany. ChangYu's ice wine with its sweet taste is targeted at the young consumer and especially female wine drinkers. These are not the only competitive strategies that ChangYu has initiated. More interesting is the vision of the global strategy of this company. For example, Chang Yu created a chateau in New Zealand, named ChangYu Kely Estate of New Zealand, by partnering with Karikari Estate of New Zealand. It is an impressive chateau and part of a notable golf enclave. ChangYu is also collaborating with Karikari to build a wine distribution network at 100 golf courses in China. Currently the wine called ChangYu Kely is largely targeting foreigners living in China, and is therefore already a powerful competitor with European wine imports. ${ }^{30}$

In June 2007, ChangYu opened the AFIP Chateau in Beijing. The target consumers are "high-end personalities" in political and business circles. The new chateau is designed to be a premium wine producing center, with an annual production of 1,000 tons, as well as a tourist and wine culture club. With the launch of the new chateau, ChangYu introduced in China a new investment mode: wine futures. ChangYu released 100 casks of 2006 wine futures for RMB180,000 each; 20 of which were bought by TXB, one of the largest European wine distributors. The new Beijing Chateau also released cellar spaces for personal storage, owners of which were entitled to a cask of the Chateau's best wine. Chang Yu has become one of the most successful wine companies in the world with a very enviable rate of profit, as illustrated in Table $1 .^{6,30}$

\section{A Chinese global vision}

ChangYu's growth is fueled by its market-orientation and global vision. This is substantiated by ChangYu's sales team having grown to over 1,500 salesmen by the end of 2007 . ChangYu ranks first in market share among Chinese wineries, with an estimated $20 \%$ of the total volume. Its strategy of partial cooperation with other large international wine groups enhances its competitiveness in the fast-growing Chinese market, while it also gains footholds in export markets for future global expansion. By the end of 2006, ChangYu wine was sold in more than 3,000 shopping malls, supermarkets, and stores in 14 European countries. In June 2006, ChangYu signed an exporting agreement with TXB. At the end of the year, 240,000 cases of ChangYu Jiebaina dry red wine had been ordered by TXB, at the time this was the single largest export order for Chinese wine. ChangYu Jiebaina also was available on Lufthansa's Asia-bound airlines. ${ }^{28}$

In a recent report of the beverage industry, ChangYu was ranked 10th in the global wine industry with sales revenue of $\$ 695$ million USD for $2007 .^{25}$ This was the first time that an Asian winery was listed as a top-10 winery. Indeed, some of the Chinese wines not only win awards, but are also shrewdly marketed for export, and the Chinese should be able to continue to increase their position in the global wine markets. Wine marketers everywhere have discussed the recent findings concerning marketability and pricing relationships. ${ }^{31}$ Surely the Chinese wine marketers are aware of the exigencies of price/quality/labeling and image relationships as anyone in the business.

Table I Financial highlights from Chang Yu

\begin{tabular}{lllll}
\hline (RMB mn) & $\mathbf{2 0 0 4}$ & $\mathbf{2 0 0 5}$ & $\mathbf{2 0 0 6}$ & $\mathbf{2 0 0 7}$ \\
\hline Revenue & 1,237 & 1,715 & 2,142 & 2590 \\
EBT & 297 & 443 & 566 & 949 \\
Net Income & 183 & 312 & 395 & 636 \\
\hline
\end{tabular}

Abbreviations: EBT; RMB.

Notes: Based on data from Euromonitor International (2006), Jenster and colleagues (2008). 
Chinese business acumen and strategic competitiveness are reason to wonder if the projected huge Chinese market will actually be an important future market for foreign exporters or alternatively will the Chinese swamp foreign markets as they have done with other products many times before. Examining the fundamental economic advantages, we see that it is not a question of whether the Chinese have an advantage in one factor of production, but actually more. With a labor force of 795.5 million, and perhaps as many as 150 million surplus rural workers available, China has a deep source of economic advantage in these factors of production and distribution. ${ }^{9}$ Essentially, with respect to wine production there is no shortage of potential laborers at low wages. Furthermore, it has about 1,400,000 kilometers of arable land. Therefore, China has bountiful agricultural potential for increasing wine production, and this would still amount to a small percentage of overall agricultural production. In addition, the modern Chinese business leaders have market savvy and there is no shortage of technologically knowledge and capability. ${ }^{25}$ Moreover, capital investment is not a problem because China has trillions of dollars of reserves available in the private and sovereign financial holdings.

\section{Conclusion}

There is no need to doubt the future of this industry or most any other industry competing with China, because China now has economic advantages like no other economy. The outcome of open competition between China and developed countries in most industries appears to be a fait accompli. While wine may not be the priority of the Chinese, they certainly appear to have the ability to command the upper hand as they have already done in other industries. China now dominates in steel production, ship building, railway equipment, consumer electronics, clothing, shoes, furniture, pharmaceuticals, and many other industrial and consumer products. The ubiquitous "Made in China" label serves to illustrate China's ability to out-compete rivals around the world. Most consumer products are now exports of China. The Chinese have rapidly gained the market advantage in many industries, leaving all the formerly top business competitors to vie for a much smaller share of the market. The issue that arises is, could this happen in the wine industry as well?

From a more general macroeconomic view, this implies a somewhat disturbing future for the traditional competitors because China's advantages forecast a global exporting country that will continue to accumulate trade surpluses and use this capital to purchase controlling interests in other countries' natural resources and industry, particularly the developed countries of Europe and America, and the less developed South American wine-producing areas, and whatever countries have valuable resources. Over the long term, no market strategies can win against the combination of absolute economic advantage in all factors of production combined with completely mobile capital and technology.

Historically, international trade usually worked to the advantage of all trading parties because the fixed boundaries between countries limited the extent of economic advantages. Some countries were better endowed in one area and others were relatively better in another. However, that is not the outcome when you awaken a sleeping giant with the opportunities of globalization. This is modern China. Of course, all of this portends a time when the rapidly increasing "trade imbalances" become too large a burden on most of the people of the competing nations. Theoretically, this could result in equilibrium when the laborer's wages in developed countries have receded to the point that they meet the rising wages within China, ceteris paribus. It makes no difference what currency is used to calculate the relative position of equilibrium because eventually real wages and consequently real wealth must move in that direction. In the meantime, an increasing number of people will chose to have a glass of wine, supplied from a multitude of vineyards under a growing umbrella of ownership, and probably increasingly in Chinese custody.

\section{Disclosure}

The authors report no conflicts of interest in this work.

\section{References}

1. McGahan AM. How industries change. Harvard Business Review. 2004 October: p. 98-106 [cited 2008 Aug 28]. Product R0410E. Available from: http://www.harvardbusinessonline.com.

2. Jennings D, Wood C. Achieving competitive advantage through design. International Journal of Wine Business Research. 1994;6:49-61.

3. Ulrich OR, Lockshin L, d'Hauteville F. The global wine business as a research field. International Journal of Wine Business Research. 2007; 19:5.

4. Cholette S, Castaldi R, Frederick A. Globalization of the wine industry: implications for old and new world producer. International Business and Economy Conference Proceedings. 2005 [cited 2007 Dec 17]. Available from http://userwww.sfsu.edu/ ibec/papers/21.pdf.

5. Euromonitor International. Industry Research Wine - China: Production, Imports and Exports. 2007 [cited 2008 Jul 11]. Available from: http://www.gmid.euromonitor.com.

6. Jenster P, Smith D, Mitry D, Jenster L. The business of wine: A global perspective. Copenhagen: CBS Press; 2008.

7. Bisson LF, Waterhouse AL, Ebeler SE, Walker MA, Lapsley JT. The present and future of the international wine industry. Nature. 2002;418:696-699.

8. Central Intelligence Agency. The World Factbook. 2007 [cited 2007 Nov 28]. Available from: http://www.cia.gov.

9. Central Intelligence Agency. The World Factbook. 2008 [cited 2008 Aug 12]. Available from: http://www.cia.gov. 
10. Fewsmith J. The political implications of China's growing middle class. Hover Institute: China Leadership Monitor. 2007;21:1-8.

11. Chunling L. Zhongguo dangdai zhongchan jieceng de goucheng ji bili. [The composition and percentage of China's contemporary middle stratum], from Shehuixue renleixue Zhongguowang. 2005 [cited 2007 Apr 18]. Available from: http://www.sachina.edu.cn/Htmldata/ article/2005/09/289.html.

12. Xiaohong Z. Zhongguo zhongchang jieceng diaocha [Survey of the Chinese middle class] Beijing: Shehui kexue wenxian chubanshe. 2005:45-47.

13. Euromonitor International, Industry Research. Country Sector Briefings, Wine - China: Trends. 2007 [cited 2007 Jul 11]. Available from: http://www.gmid.euromonitor.com.

14. Sun ZJ. Development after the establishment of the P.R.C. 2005 [cited 2007 Apr 25]. Available from: http://www.winechina.com.

15. Sun ZJ. Birth of the modern wine industry. 2003 [cited 2007 Apr 25]. Available from: http://www.winechina.com.

16. Shao-Hua L. Grape Production in China. Bejing, People's Republic of China: Department of Fruit Sciences, College of Horticulture, China Agricultural University; 2007.

17. Tagliabue J. Chinese put down roots in Bordeaux. 2008 [cited 2008 Mar 3]. Available from: http://iht.nytimes.com/articles/2008/02/26/ europe/journal.php?page $=1$.

18. Wine Institute. World vineyard acreage. 2007 [cited 2008 Aug 12]. Available from: http://www.wineinstitute.org/resources/worldstatistics/ article126.

19. Berberoglu H. Chinese wine history and modern wine. 2004 [cited 2007 May 11]. Available from: http://www.foodreference.com/html/ artchinesewine.

20. Workman D. China's wine treasure. 2006 [cited 2007 Mar 3]. Available from: http://www.wines-info.com/html/189/20067311110421.html.

21. Xu GR. Grandiose survey of Chinese alcoholic drinks and beverages. Research Paper. 2000 [cited 2007 Apr 25]. Available from: http://www. jiangnan.edu.cn/zhgjiu/j5-2.htm\#1.
22. Chen J. Who can change the Chinese people's consumption patterns? Wine Business Monthly. 2003 [cited 2007 Apr 30]. Available from: www.winebusiness.com/html/MonthlyArticle.cfm?dataid=27898.

23. ISI Emerging Markets Database. Wine in China: A market analysis. 2006 [cited 2007 Jul 10]. Available from: http://site.securities.com/.

24. Jenster P, Cheng Y. Dragon Wine: developments in Chinese wine industry. International Journal of Wine Business Research. 2008;20:244-259.

25. Wang J. 2010 Global wine market outlook. China Trade News. Mar 18, 2008 [cited 2008 May 22];18(16):31-53. Available from: http://www. wines-info.com.

26. Balfour F, Matlack C. Potations from Chairman Mao: Can China produce fine wines? There's big money betting that it can. Business Week. Sep 29, 2006 [cited 2008 Sep 7]. Available from: http://www.businessweek. com/globalbiz/content/sep2006/gb20060929_998821.htm.

27. Wine Industry Report. Future of wine in China outlined in CAWG Report. 2006 [cited 2007 Dec 29]. Available from: http://wineindustryreport. finewinepress.com/2006/05/22/future-of-wine-in-china-outlined-incawg-report/.

28. Buckalew L. Shanghai wine brief 2005. Global Agriculture Information. 2005 [cited 2008 Jan 5]. Available from: http://www.fas.usda.gov/ gainfiles/200504/146119409.doc.

29. Johnson Q. China's imports of bottled wine hit the record of 54 million bottles. 2008 [cited $2008 \mathrm{Jul}$ 6]. Available from: http://www.wines-info. com/Newshtml/200803/1942008032911180808.html.

30. Euromonitor International. Company research: Yantai ChangYu Group Co. Ltd - Company background. 2006 [cited 2007 Apr 18]. Available from: http://www.gmid.euromonitor.com.

31. Lecocq S, Visser M. What determines wine prices: Objective vs. sensory characteristics. J Wine Econ. 2006;1:42. 
